\title{
Light And Oxygen Impelling Rubrivivax Gelatinosus Directly Used Food Processing Wastewater To Accumulate Poly- $\beta$-Hydroxybutyrate, 5- Aminolevulinic Acid, Pigment
}

\section{Pan Wu}

Guangzhou Institute of Industrial Technology

Xiaohan Xu (D104595978@qq.com)

South China University of Technology https://orcid.org/0000-0003-4382-1004

\section{Research}

Keywords: R. gelatinosus, light-oxygen, macromolecular organics wastewater, bioresource productions, two component signal transduction system

Posted Date: August 10th, 2021

DOl: https://doi.org/10.21203/rs.3.rs-789544/v1

License: (c) (i) This work is licensed under a Creative Commons Attribution 4.0 International License. Read Full License 


\section{Abstract}

Background: Rubrivivax gelatinosus have the advantage of using wastewater to realize biomass recovery. However, they still cannot be large-scale applied because they cannot directly treat the wastewater containing macromolecular organics. Thus, this paper investigated the effect of light-oxygen condition on Rubrivivax gelatinosus ( $R$. gelatinosus) directly recycling wastewater containing macromolecular organics to produce biomass, poly- $\beta$-hydroxybutyrate (PHB), 5-Aminolevulinic acid (5-ALA), pigment.

Results: $R$. gelatinosus directly treated the macromolecules organic (soybean protein and starch) wastewaters and achieved biomass recovery under light-anaerobic and light-micro oxygen in six conditions. COD, protein, starch removals for two wastewaters all reached above $70 \%$. Renewable bioresource such as biomass, PHB, 5-ALA, pigment productions were 10 times of initial content. Theoretical analysis indicated that light activated two component signal pathway by stimulating its first $h k$ gene expression, which regulated synthesis of protease and amylase. However, oxygen concentration decided the level of gene expression and the amount of enzymes. When oxygen was at micro-oxygen or anaerobic, above these expression and synthesis were conducted.

Conclusion: In summary, this study expanded the view point ignored by traditional theory. It was realized that PNSB directly treated wastewater and accumulated nutrients (biomass, PHB, pigment and 5-ALA) for recycling, which reduced the secondary pollution of excess sludge to the environment.

\section{Introduction}

Purple non-sulfur bacteria (PNSB) are a photosynthetic bacteria [1-3]. They can realize the wastewater purification and the recycling of biomass resource simultaneously. So far, scientists have used PNSB to treat a variety of wastewaters [4-6]. Meanwhile, PNSB biomass is valuable resource for biochemical substances such as single cell protein, bio-polymers, antimicrobial agents, pantothenic acid and therapeutic compounds, and is nontoxic and harmless $[7,8]$. So, PNSB are regarded as suitable renewable raw materials for producing the natural biochemical substances. Therefore, PNSB wastewater treatment technology avoids the excess sludge problems because the generated bacterial mass can be re-utilized as resources. In a variety of waste-waters, the nontoxic and harmless class wastewater is the optimal for PNSB biomass resource recycling.

In spite that the PNSB wastewater treatment technology has above many advantages, it still cannot realize industrial application due to the limitation of a traditional theory. This is because that the nontoxic and harmless wastewater usually contains a large number of macromolecular organic matters. According to the microbial ecological succession law [9-11], the large population of heterotrophic bacteria was observed firstly in nature organic wastewater. At the same time, the macromolecules (macromolecular carbohydrates, protein) were degraded into small molecules (monosaccharide, lower fatty acid, amino acid). Afterwards, the heterotrophic bacteria slowly reduced and PNSB increased rapidly. These indicated that PNSB could not decompose macromolecular organic and only directly 
utilized small molecules. Thus, the traditional theory stated that PNSB could not directly treat wastewater containing macromolecular organics. They included most type of nontoxic wastewaters suitable for PNSB treatment such as protein and polysaccharide wastewaters [9-11].

The traditional theory restricts the direct application of PNSB wastewater treatment technology. As a result, the pretreatment (i.e., solubilization treatment) is often applied to degrade macromolecules into small ones in PNSB wastewater treatment. Then, PNSB are utilized for following treatment in wastewaters containing macromolecular organics [9-11].

However, the pretreatment not only increases the cost, energy consumption and treatment process, but also consumes the organic substances which otherwise can be used by PNSB to synthesize biomass. Besides, PNSB may also be contaminated by infectious bacteria from pretreatment process, making that PNSB biomass cannot be recycled and reused as resource. So, the achieving PNSB direct treatment of macromolecular organic wastewater is very important for the wide application of PNSB wastewater treatment technology.

Rubrivivax gelatinosus are an PNSB [2, 12]. Prior to experiment in medium [13-16], it was found that $R$. gelatinosus could secrete extracellular enzyme (protease and amylase). This suggested that $R$. gelatinosus could degrade macromolecular organic (protein and starch), and thus had the potential of directly treating wastewaters containing macromolecular organic.

However, in previous studies for $R$. gelatinosus, most efforts were committed to the wastewater treatment after pretreatment [2], the photosynthetic structure [17] and hydrogen production [18]. Little information is reported concerning the $R$. gelatinosus direct treatment of wastewaters containing macromolecular organic. So far, it is yet unknown whether $R$. gelatinosus can directly treat the macromolecules organic wastewater. In addition, the light and oxygen conditions is the most important for $R$. gelatinosus. They influence the multiple metabolic activities of $R$. gelatinosus [19-21], and then may impact on $R$. gelatinosus direct treatment of the wastewaters containing macromolecules organic.

Therefore, the objectives of the current research are (i) to clarify whether $R$. gelatinosus can directly treat the wastewaters containing macromolecules organic; (ii) to investigate the effect of light-oxygen conditions on $R$. gelatinosus directly treatment of wastewaters containing macromolecules organic and biomass, poly- $\beta$-hydroxybutyrate (PHB), 5-Aminolevulinic acid (5-ALA), pigment productions. The typical wastewaters containing macromolecules organic, namely soybean protein and starch wastewaters, were chosen for this study.

\section{Results}

The effect of light-oxygen conditions on $\boldsymbol{R}$. gelatinosus directly treating wastewaters and resource recycling 
In order to clarify whether $R$. gelatinosus can directly treat the wastewaters containing macromolecules organic and the effect of light-oxygen conditions on $R$. gelatinosus direct treatment of wastewaters, the COD removals for soybean protein and starch wastewaters were respectively tested under six different light-oxygen conditions. The results were presented in Fig. 1.

As Fig. 1 showed, the COD removals for soybean protein wastewater and starch wastewater increased gradually under light-micro oxygen and light-anaerobic conditions. After 96 hours treatment, under lightanaerobic conditions, the COD removals for soybean protein wastewater and starch wastewater were around $80 \%$ and $70 \%$ respectively. Under light-micro oxygen conditions, the COD removals for above two wastewaters reached around $70 \%$ and $60 \%$ respectively. The COD removals of two wastewaters were higher under light-anaerobic conditions than light-micro oxygen conditions.

Moreover, it was seen from Fig. 1 that under dark-aerobic, dark-anaerobic, dark-micro oxygen and lightaerobic conditions, the COD removals for both two wastewaters reached around $23 \%$ and $5 \%$ respectively after 96 hour. Moreover, their COD removals almost had not change after 24 hours. This was because the soybean protein wastewater and starch wastewater contained around $23 \%$ and $5 \%$ small molecules respectively. After 24 hours, the small molecules were exhausted. Thus, COD removal almost had not change after 24 hours. These suggested that $R$. gelatinosus could not directly treat the soybean protein wastewater and starch wastewater under dark-aerobic, dark-anaerobic, dark-micro oxygen and lightaerobic conditions. Furthermore, as Fig. S2 showed, the domesticated $R$. gelatinosus also had same result with Fig. 1 for COD removals in two wastewaters.

Simultaneously, as shown in Table. 2, after 96 hours treatment, $R$. gelatinosus biomass, poly- $\beta$ hydroxybutyrate (PHB), 5-Aminolevulinic acid (5-ALA), pigment productions in two wastewaters increased significantly under light-micro oxygen and light-anaerobic conditions. The biomass, PHB, pigment and 5ALA contents reached at least $2000,0.6,198,0.085 \mathrm{mg} / \mathrm{L}$ in two wastewaters, respectively. Under lightanaerobic conditions, the biomass, PHB, pigment and 5-ALA contents were at least 10 times of initial content in two wastewaters. Under other four light and oxygen conditions, the biomass, PHB, 5-ALA, pigment productions increased slightly or decreased after 96 hours, which was consistent with the result in Fig. 1.

These results indicated that $R$. gelatinosus could directly treat the wastewaters containing macromolecules organic and biomass resource recycling, which was different from the understanding of traditional theory. This was because the traditional theoretical perspective studied the ecological succession of mixed bacteria in natural organic wastewater. After ecological succession, $R$. gelatinosus only could use the small molecules in wastewater. In this study, the pure $R$. gelatinosus were used directly to treat the wastewaters containing macromolecules organic from the point of wastewater treatment. There was not the microbial ecological succession in wastewater of this work. Therefore, under appropriate light-oxygen conditions, $R$. gelatinosus demonstrates the characteristic of directly treating the wastewaters containing macromolecules organic. In short, the results of this paper expanded the 
understanding of traditional theory for PNSB (R. gelatinosus) directly purifying the macromolecules organic wastewaters.

\section{The effect of light-oxygen conditions on protein removal in soybean protein wastewater and starch removal in starch wastewater}

Generally, the macromolecules organic wastewaters contain a large number of macromolecular organic substances. The soybean protein and starch wastewaters are constituted mainly by protein and starch respectively, which are the main source of COD in relevant wastewater. Figure 1 showed that $R$. gelatinosus could directly treat the two wastewaters and removed greatly COD under light-micro oxygen and light-anaerobic conditions. These indicate that $R$. gelatinosus may remove the macromolecular organic substances (protein and starch) in soybean protein and starch wastewaters.

Thus, the effect of light-oxygen conditions on the protein removal in soybean protein wastewater and the starch removal in starch wastewater were measured respectively. As Fig. 2 demonstrated, under lightmicro oxygen and light-anaerobic conditions, the protein in soybean protein wastewater and the starch in starch wastewater were removed greatly by $R$. gelatinosus. This proved that $R$. gelatinosus could remove the protein and starch in two wastewaters. Moreover, the protein and starch removals were the highest under light-anaerobic conditions. In addition, it could be observed from Fig. 2 that the protein and starch in relevant wastewater were not removed under other four conditions. This indicated that $R$. gelatinosus could not remove the protein and starch in wastewater under other conditions. These results were consistent with the results in Fig. 1.

\section{The effect of light-oxygen conditions on protease activity in soybean protein wastewater and amylase activity in starch wastewater}

Figure 2 indicated that $R$. gelatinosus could remove the protein and starch in wastewater under lightmicro oxygen and light-anaerobic conditions. This might related to the synthesis and secretion of extracellular enzymes because the removal of both protein and starch needed the involvement of corresponding extracellular enzymes (protease and amylase).

Therefore, in order to clarify the effect of light-oxygen conditions on the synthesis and secretion of protease and amylase, the protease activity in soybean protein wastewater and amylase activity in starch wastewater were measured respectively.

As Fig. 3 indicated, $R$. gelatinosus secreted the protease and amylase in macromolecular organic wastewater environment under light micro-oxygen and light-anaerobic conditions. This explained why $R$. gelatinosus directly treated the soybean protein and starch wastewaters only under light micro-oxygen and light-anaerobic conditions. Furthermore, the protease and amylase activities in waste-waters were higher under light-anaerobic condition than light micro-oxygen condition. Therefore, COD, protein and starch removals were the best under light-anaerobic condition. 


\section{Discussion}

Figures 1-3 showed $R$. gelatinosus could directly treat the soybean protein and starch wastewaters under light micro-oxygen and light-anaerobic conditions, but could not under other light-oxygen conditions. According to [22], light and oxygen were the most important factors for $R$. gelatinosus. For light, it was necessary condition of photosynthesis (PS), and determined the PS and expressions of PS genes in $R$. gelatinosus. As an external stimulus, light also regulated a variety of metabolic activities and signal transduction pathways for $R$. gelatinosus. According to [23], two component signal transduction system (TCSTS) was a kind of signal transduction system existing in bacteria. TCSTS participated in a variety of physiological and biochemical processes, and was the regulatory mechanism of its metabolic activities (the synthesis of protease, amylase) [23]. As shown in Table 3, the first gene ( $h k$ ) in TCSTS was expressed under light micro-oxygen and light anaerobic conditions, but not under other conditions. At the same time, the activities of protease, lipase and amylase were observed under the conditions of light micro-oxygen and light anaerobic (Fig. 3). These suggested that light stimulated and activated TCSTS pathway with the expression of first gene $h k$. After that, the light regulated the synthesis of protease and amylase of $R$. gelatinosus through TCSTS pathway. As shown in Figs. 1-2, COD, protein, starch were degraded and removed.

However, neither enzyme nor gene still was detected under light aerobic condition (Fig. 3, Table. 3). The main reason was the oxygen. For oxygen, it had inhibitory effect on the expression of related gene $h k[19$, $20,21]$. Moreover, oxygen concentration decided the level of gene expression. Then, the synthesis and activity of enzyme was affected also. According to previous literature [19, 20, 21], oxygen tension in environment determined the oxygen-dependent transcription of PS genes. In this study, under saturation oxygen tension (aerobic) conditions, the transcription of the related gene ( $h k$ ) was inhibited totally. Under micro-oxygen conditions, the related gene ( $h k$ ) expression and enzyme synthesis were not inhibited completely, and were expressed and synthesized normally and partly as the oxygen content decreases. Meanwhile, under anaerobic conditions, the related gene ( $h k$ ) and enzymes were expressed and synthesized fully. This explained why the protease and amylase activities in wastewaters were the highest under light-anaerobic condition (Fig. 3). It was concluded from this work that for R. gelatinosus, light stimulated the expression of the related gene $(h k)$ and the synthesis of enzyme. However, oxygen concentration decided the level of gene expression and the amount of enzymes.

The natural water body environment belonged to light aerobic or dark anaerobic conditions. Under two conditions, the related gene ( $h k$ ) was not expressed, and enzyme was not synthesized. Sometime, the natural water body also might be low light micro-oxygen. Even if the enzyme was synthesized under this light-oxygen. But, the enzyme activity was very low during 24 hours based on Fig. 3 . At this time, the amount of organic matter absorbed by $R$. gelatinosus was very small. So, they could not grow and reproduce rapidly. Meanwhile, heterotrophic microorganisms secreted many the degrading enzymes. Therefore, they occupied the vast majority of organic matter and reproduced in large quantities. Therefore, the traditional theory thought they could not degrade macromolecular organic matter. However, 
R. gelatinosus wastewater treatment technology had advantages that could not be ignored, namely, no secondary pollution to the environment because biomass recycling.

As shown in Table. 2, the growth and the content of PHB, 5-ALA, pigment were significantly increased with the removal of organic compounds in the two wastewaters by $R$. gelatinosus. This was due to the light and oxygen conditions controlling the synthesis of degrading enzyme of $R$. gelatinosus. These enabled $R$. gelatinosus to utilize the organic matter in wastewater to produce the cell yield, PHB, pigment and 5-ALA contents. Previous studies had used wastewater as a medium to produce PHB and pigments for other microorganisms. Rahman et al., 2015 [24] studied that microalgae produced PHB using a wastewater as media. Hashemi et al., 2021 [25] used the yeast wastewater to produce pigments by filamentous fungi. In this work, it was completed that $R$. gelatinosus directly used food processing wastewater to produce the PHB, 5-ALA and pigment, which reduced the secondary pollution of excess sludge to the environment.

\section{Materials And Method}

\section{Materials}

In this study, Rubrivivax gelatinosus were used, a wide strain isolated from fish pond [26]. It was cultured in a thermostat shaker $\left(120 \mathrm{rpm}, 30^{\circ} \mathrm{C}\right.$ ) with the improved RCVBN medium (Supplemental material Sect. 1) for 48 hour before use. The inoculated $R$. gelatinosus was at the logarithmic growth phase.

Typically, the polysaccharide and protein were the macromolecular substances (natural organic matters). In this work, the corresponding macromolecular organic wastewater was the starch wastewater and soybean protein wastewater respectively. All two macromolecular organic wastewaters were high concentration organic wastewater, containing a lot of macromolecular organic pollutants. A large number of emissions of three wastewaters would cause the serious environmental pollution problems. In addition, they were also typical non-hazardous, high nutrient, and were rich in substrates for $R$. gelatinosus growth. Thus, they were selected for this study.

The soybean protein wastewater and starch wastewater were obtained respectively from the Guangzhou Soybean Products Machining Factory and Guangzhou Starch Processing Plant. They were filtered firstly by 100 hole net. Afterwards, the wastewaters were diluted using water. Finally, the characteristics of soybean protein wastewater were as follows (all in $\mathrm{mg} / \mathrm{L}$ ): COD was around 6000 , protein was around 3200 ; the characteristics of starch wastewater were as follows (all in mg/L): COD was around 6700, starch was around 6100.

\section{Experimental setup}

Bioreactors were presented in Fig. S1. The bioreactors were washed and then were sterilized at $121^{\circ} \mathrm{C}$ for $30 \mathrm{~min}$ before use. For batch culturing, $600 \mathrm{ml}$ soybean protein and starch wastewaters were added to the 
two different bioreactors respectively. After bottling, two bioreactors containing different wastewaters were sterilized at $121^{\circ} \mathrm{C}$ for $30 \mathrm{~min}$. After sterilization, these bioreactors containing wastewater were placed in the sterilized ultra clean cabinet until cooling. Afterwards, R. gelatinosus in exponential growth was inoculated with an initial concentration of $191.8 \mathrm{mg} / \mathrm{L}$ (dry cell weight) in sterilized ultra clean cabinet. The wastewater and $R$. gelatinosus were cultured in a thermostat shaker $\left(120 \mathrm{rpm}, 26-30^{\circ} \mathrm{C}\right)$ under sterile conditions.

\section{Light oxygen conditions}

In this work, the illumination condition was achieved by 100 watt tungsten filament light bulbs; the oxygen condition was realized by aeration; the dissolved oxygen (DO) concentration was controlled by regulating the flow-rate of oxygen gas into the bioreactor. The light-oxygen conditions were set as follows:

Light: the light intensity was kept at around 3000 lux by adjusting the distance between the bioreactor and the bulbs.

Dark: in order to keep out of light transmission, bioreactor was covered by four layers of black cloth.

Anaerobic condition: after saturated with nitrogen (the purity of nitrogen was $98.0 \%$ ), the bioreactor was sealed with sealing membrane to keep absolute anaerobic condition.

Micro oxygen condition was realized by micro aeration (the purity of oxygen was $98.5 \%$ ) and the DO concentration in bioreactor was kept within $0.09 \mathrm{mg} / \mathrm{L}$;

Aerobic condition was realized by aeration and the DO concentration in the bioreactor was kept around $2.0 \mathrm{mg} / \mathrm{L}$.

\section{Analysis methods}

Wastewater sample $(5 \mathrm{~mL})$ was collected from different bioreactors and was centrifuged at $9000 \mathrm{rpm}$ for $10 \mathrm{~min}$. The supernatant was used to test the COD; the content of protein and starch and the amylase and protease activity in wastewater. The collected $R$. gelatinosus were used to measure the biomass, poly- $\beta$-hydroxybutyrate (PHB), 5-Aminolevulinic acid (5-ALA), pigment productions. The $\mathrm{pH}$ was measured using $\mathrm{pH}$ meter and the DO was measured using DO meter. The biomass (dry cell weight) and COD were tested by the APHA (American Public Health Association) standard methods.

PHB, 5-ALA productions were tested using spectrophotometer (ThermoSpectronic, Rochester, NY) at 235 and 480, respectively. Pigment (chloromycetin and carotenoids) productions were tested using spectrophotometer at 663,646 and 470 , respectively. The detailed process was completed according to [27-30].

\section{Determination of protease and amylase activity in wastewater}


Protease activity was measured using $0.5 \%$ azocasein in $20 \mathrm{mmol} / \mathrm{L}$ Tris $\mathrm{HCl}$ buffer $\mathrm{pH}$. The substrate $(800 \mu \mathrm{l})$ was mixed with $200 \mu \mathrm{l}$ of supernatant (wastewater) and incubated for $1 \mathrm{~h}$ at $30{ }^{\circ} \mathrm{C}$. Then, $500 \mu \mathrm{l}$ of $15 \%$ trichloroacetic acid was added. After 30 min incubation at room temperature, the reaction mixture was centrifuged at 14,000 rpm using an eppendorf centrifuge. The clear supernatant (800 $\mu \mathrm{l})$ was mixed with $200 \mu \mathrm{l}$ of $2 \mathrm{~mol} / \mathrm{L} \mathrm{NaOH}$. Absorbance of the resulting colored compound was measured by spectrophotometer (ThermoSpectronic, Rochester, NY) at 440nm against a reagent blank. One unit of protease activity was defined as the amount of enzyme which result in an absorbance increase of 0.01 at $440 \mathrm{~nm}[31,32]$.

Amylase activity was measured using the modified method of Bernfeld [32]. The assay system contained $0.5 \mathrm{ml}$ of supernatant (wastewater) and $0.5 \mathrm{ml}$ of $1.0 \%$ soluble starch solution ( $\mathrm{pH} 6.9$ in phosphate buffer, $0.004 \mathrm{~mol} / \mathrm{L})$, incubating at $50{ }^{\circ} \mathrm{C}$ for $10 \mathrm{~min}$. Amylase activity was measured by colorimetry at $540 \mathrm{~nm}$ using a spectrophotometer (ThermoSpectronic, Rochester, NY) against an appropriate blank. One unit of enzyme activity was defined as the amount of enzyme that releases $1 \mu \mathrm{mol}$ of glucose per min.

\section{The determination of protein and starch content in wastewater}

The determination of protein in wastewater was conducted according to Kjeldahl determination using the fully automatic Kjeldahl instrument. The china national food safety standard GB 5009.5-2010 (2010). The starch content in wastewater was measured through the enzymatic hydrolysis. The china national Food Safety Standard GB/T 5009.9-2008 (2008).

\section{RNA extraction and qPCR}

RNAs were extracted from $R$. gelatinosus in soybean protein wastewater and starch wastewater respectively, using an RNeasy Midi kit (Qiagen) according to a previously described protocol [20,33, 34]. cDNA was prepared from total RNA by use of SuperScript II (Stratagene) and random hexamers as described earlier $[20,33,34]$. cDNA samples were used for quantitative reverse transcription-mediated real-time PCR (qPCR) [20, 33, 34]. The iCycler iQ real-time PCR detection system (Bio-Rad) with SYBR green chemistry was used to monitor amplification and to quantify PCR products $[20,33,34]$. The primers and amplification conditions were described in Table. 1 [23]; expression levels of the histidine kinase ( $h k$ ) gene were used for normalization [20,33,34]. Each qPCR reaction was performed at least in triplicate; average data was reported [20,33,34].

\section{Statistical analysis}

In experiments, parallel samples and parallel detections were conducted in order to ensure the accuracy of data. Each reported value was obtained from three or more parallel samples data and the error of these data did not exceed $5 \%$.

\section{Conclusion}


This study expanded the view point of traditional theory ( $R$. gelatinosus untreating directly wastewater). Under light-anaerobic and light-micro oxygen, $R$. gelatinosus directly treated the macromolecules organic wastewaters and biomass, PHB, 5-ALA, pigment productions were enhanced. Light activated TCSTS pathway by stimulating its first $h k$ gene expression, which regulated synthesis of protease and amylase. However, oxygen inhibited above these expression and synthesis. Only oxygen is at micro-oxygen or anaerobic, above expression and synthesis are conducted. It was realized that $R$. gelatinosus directly treated wastewater and accumulated nutrients for recycling, which reduced the secondary pollution of excess sludge to the environment.

\section{Declarations}

\section{Acknowledgement}

Not applicable.

\section{Authors' contributions}

Pan Wu: Complete the experiment and write the paper; Xiaohan Xu: Guidance and modification.

\section{Funding}

This work is supported by the startup research fund.

\section{Availability of data and materials}

The datasets used and/or analyzed during the current study are available from the corresponding author on reasonable request.

\section{Ethics approval and consent to participate}

Not applicable.

\section{Consent of publication}

Not applicable.

\section{Competing interests}

The authors declare that they have no competing interests.

\section{Author details}

a School of Civil Engineering, Guangzhou Institute of Science and Technology, Guangzhou, 510540, China. ${ }^{b}$ School of Civil Engineering and Transportation, South China University of Technology, Guangzhou, 510641, China. 


\section{References}

1. Asao M, Pinkart HC, Madigan MT. Diversity of extremophilic purple phototrophic bacteria in Soap Lake, a Central Washington (USA) Soda Lake. Environ Microbiol. 2011;13:2146-2157.

2. Choorit W, Thanakoset $\mathrm{P}$, Thongpradistha J, Sasaki K, Noparatnaraporn N. Identification and cultivation of photosynthetic bacteria in wastewater from a concentrated latex processing factory. Biotech Lett. 2002;24:1055-1058.

3. Chen JQ, Wei JJ, Ma C, Yang ZZ, Li ZH, Yang X, Wang MS, Zhang HQ, Hu JW, Zhang C. Photosynthetic bacteria-based technology is a potential alternative to meet sustainable wastewater treatment requirement? Environ Int. 2020;137:105417.

4. Zilles JL, Peccia J, Kim MW, Hung CH, Noguera DR. Involvement of Rhodocyclus-related organisms in phosphorus removal in full-scale wastewater treatment plants. Appl Environ Microbiol. 2002;68: 27632769 .

5. Dong XL, Zhou JT, Liu Y. Peptone-induced biodecolorization of Reactive Brilliant Blue (KN-R) by Rhodocyclus gelatinosus XL-1. Process Biochem. 2003;39: 89-94.

6. Kobayashi M and Kurata S. The mass culture and cell utilization of photosynthetic bacteria. Process Biochem. 1978;13:27-30.

7. Greene AF and Mascarenhas JP. Coenzyme Q: intracellular distribution in Rhodospirillum rubrum. Science. 1964;80:1455-1456.

8. Jensen SL, Cohen-Bazire G, Stanier RY. Biosynthesis of carotenoids in purple bacteria: A re-evaluation based on considerations of chemical structure. Nature. 1961;192:1168-1172.

9. Siefert E, Irgens RL, Pfennig N. Phototrophic purple and green bacteria in a sewage treatment plant. Appl Environ Microbiol. 1978;35:38-44.

10. Kobayashi $\mathrm{M}$ and Tchan YT. Treatment of industrial waste solutions and production of useful byproducts using a photosynthetic bacterial method. review. Water Res. 1973;7:1219-1224.

11. Kobayashi M and Tchan YT. Formation of dimethylnitrosamine in polluted environment and the role of photosynthetic bacteria. Water Res. 1978;12:199-201.

12. Zhi R, Cao KF, Zhang GM, Zhu J, Xian G. Zero excess sludge wastewater treatment with value-added substances recovery using photosynthetic bacteria. J Clean Prod. 2020;250:119581.

13. Buranakarl L, Ito K, Izaki K, Takahashi H. Purification and characterization of a raw starch-digestive amylase from non-sulfur purple photosynthetic bacterium. Enzyme Microb Tech. 1998;10:173-179. 
14. Hyun MS, Okuda SI, Izaki K. Purification and characterization of a neutral serine protease from nonsulfur purple photosynthetic bacterium. Curr Microbiol. 1989;18:179-383.

15. Oda K, Tanskul S, Oyama H, Noparatnaraporn N. Purification and characterization of alkaline serine protease from photosynthetic bacterium, Rubrivivax gelatinosus KDDS1. Biosci Biotechnol Biochem. 2004;68:650-655.

16. Tanskul S, Oda K, Oyama H, Noparatnaraporn N, Tsunemi M, Takada K. Substrate specificity of alkaline serine proteinase isolated from photosynthetic bacterium, Rubrivivax gelatinosus KDDS1. Biochem Biophys Res Commun. 2003;309:547-551.

17. Ranck JL, Halgand F, Laprevote O, Reiss-Husson F. Characterization of the core complex of Rubrivivax gelatinosus in a mutant devoid of the LH2 antenna. Biochimica Et Biophysica Acta. 2005;1709:220-230.

18. Maness PC and Weaver PF. Hydrogen production from a carbon-monoxide oxidation pathway in Rubrivivax gelatinosus. Int J Hydrogen Energ. 2002;27:1407-1411.

19. Pemberton JM, Horne IM, McEwan AG. Regulation of photosynthetic gene expression in purple bacteria. Microbiology. 1998;144:267-278.

20. Gomelsky L, Moskvin OV, Stenzel RA, Jones DF, Donohue TJ, Gomelsky M. Hierarchical regulation of photosynthesis gene expression by the oxygen-responsive PrrBA and AppA-PpsR Systems of Rhodobacter sphaeroides. J Bacteriol. 2008;80:8106-8114.

21. Bauer C, Elsen S, Swem LR, Swem DL, Masuda S. Redox and light regulation of gene expression in photosynthetic prokaryotes. Phil Trans R Soc Lond B. 2003;358:147-154.

22. Yang AQ, Peng M, Zhang GM, Meng F, Zhang Y, Zou ZG. Effects of light-oxygen conditions on microbial community of photosynthetic bacteria during treating high-ammonia wastewater. Process Biochem. 2018;72:137-142.

23. Cho SY and Yoon Si. Crystal structure of the antibiotic- and nitrite-responsive histidine kinase VbrK sensor domain from Vibrio rotiferianus. Biochem Biophys Res Commun. 2021;568:136-142.

24. Ranchou-Peyruse A, Herbert R, Pierre CP, Guyoneaud R. Comparison of cultivation-dependent and molecular methods for studying the diversity of anoxygenic purple phototrophs in sediments of an eutrophic brackish lagoon. Environ Microbiol. 2006;8:1590-1599.

25. Hashemi SS, Karimi K, Taherzadeh MJ. Integrated process for protein, pigments, and biogas production from baker's yeast wastewater using filamentous fungi. Bioresource Technol. 2021;337:125356.

26. Xu SN, Qiu HD, Lin J, Chen CY. On the isolation, identification and function of purple non-sulfer photosynthetic bacteria. J Fuzhou Univer (Natural Science) China. 2004;32:246-251. 
27. Wellburn AR. The spectral determination of chlorophylls a and b, as well as total carotenoids, using various solvents with spectrophotometers of different resolution. J Plant Physiol. 1994;144:307-313.

28. Dhaliwal MK and Chandra N. Optimization of carotenoids production by Rhodotorula mucilaginosa (MTCC-1403) using agro-industrial waste in bioreactor: A statistical approach. Biotech Rep. 2020;25:407.

29. Rahman A, Putman RJ, Inan K, Sal FA, Sathish A, Smith T, Nielsen C, Sims RC, Miller CD.

Polyhydroxybutyrate production using a wastewater microalgae based media. Algal Res. 2015;8:95-98.

30. Li Al, Liang CL, Xu LH, Wang YY, Liu W, Zhang KX, Liu JJ, Shi JJ. Boosting 5-ALA-based photodynamic therapy by a liposomal nanomedicine through intracellular iron ion regulation. Acta Pharm Sin B. 2021;11:1329-1340.

31. Gessesse A, Dueholm T, Petersen SB, Nielsen PH. Lipase and protease extraction from activated sludge. Water Res. 2003;37:3652-3657.

32. Zhang B, He PJ, Lu F, Shao LM, Wang P. Extracellular enzyme activities during regulated hydrolysis of high-solid organic wastes. Water Res. 2007;41:4468-4478.

33. Gomelsky L, Sram J, Moskvin OV, Horne IM, Dodd HN, Pemberton JM, McEwan AG, Kaplan S, Gomelsky M. Identifification and in vivo characterization of PpaA, a regulator of photosystem formation in Rhodobacter sphaeroides. Microbiology. 2003;149:377-388.

34. Pappas CT, Sram J, Moskvin OV, Ivanov PS, Mackenzie RC, Choudhary M, Land ML, Larimer FW, Kaplan S, Gomelsky M. Construction and validation of the Rhodobacter sphaeroides 2.4.1 DNA microarray: transcriptome fflexibility at diverse growth modes. J Bacteriol. 2004;186:4748-4758.

\section{Tables}

Table. 1 The primers and amplification conditions of the histidine kinase ( $h k)$ gene 
Primer $\quad$ Reaction conditions

HK 5'-3' ATAGCAACGGCAGGGATT

$94^{\circ} \mathrm{C} 5 \min 94^{\circ} \mathrm{C} 30$ s $55^{\circ} \mathrm{C} 20$ s $72^{\circ} \mathrm{C} 20$ s 30 cycles

HK 3'-5' TTGAAGGGTGCATAGGTG

GAPDH 5'-3' ACCACAAACTGCCTTGCTCC

$94^{\circ} \mathrm{C} 5 \min 94^{\circ} \mathrm{C} 30$ s $59^{\circ} \mathrm{C} 40$ s $72^{\circ} \mathrm{C} 30$ s 30 cycles

GAPDH 3'-5' ATGCTCGACCTGCTGTCACC

Table. 2 The productions of biomass, PHB, pigment, 5-ALA under different light and oxygen conditions at 0,96 hours in: (A) soybean protein wastewater (B) starch wastewater 
(A)

Soybean protein wastewater $(\mathrm{mg} / \mathrm{L})$

\begin{tabular}{|c|c|c|c|c|}
\hline & Biomass & PHB & Pigment & 5-ALA \\
\hline $\begin{array}{l}\text { All light-oxygen } \\
\text { (0 hour) }\end{array}$ & 191.8 & 0.058 & 19.0 & 0.007 \\
\hline $\begin{array}{c}\text { Dark-aerobic } \\
\text { (96 hour) }\end{array}$ & 525.0 & 0.157 & 51.9 & 0.017 \\
\hline $\begin{array}{l}\text { Dark-anaerobic } \\
\text { ( } 96 \text { hour) }\end{array}$ & 523.0 & 0.156 & 51.8 & 0.018 \\
\hline $\begin{array}{l}\text { Dark-micro oxygen } \\
\text { ( } 96 \text { hour) }\end{array}$ & 527.0 & 0.158 & 52.2 & 0.019 \\
\hline $\begin{array}{l}\text { Light-aerobic } \\
\text { (96 hour) }\end{array}$ & 529.0 & 0.159 & 52.4 & 0.021 \\
\hline $\begin{array}{l}\text { Light-anaerobic } \\
\text { ( } 96 \text { hour) }\end{array}$ & 2000.8 & 0.613 & 198.0 & 0.085 \\
\hline $\begin{array}{l}\text { Light-micro oxygen } \\
\text { ( } 96 \text { hour) }\end{array}$ & 1592.8 & 0.478 & 157.7 & 0.065 \\
\hline
\end{tabular}


(B)

Starch wastewater $(\mathrm{mg} / \mathrm{L})$

\begin{tabular}{|c|c|c|c|c|}
\hline & Biomass & РHB & Pigment & 5-ALA \\
\hline $\begin{array}{l}\text { All light-oxygen } \\
\text { (0 hour) }\end{array}$ & 191.8 & 0.058 & 19.0 & 0.007 \\
\hline $\begin{array}{c}\text { Dark-aerobic } \\
\text { (96 hour) }\end{array}$ & 200 & 0.062 & 19.8 & 0.008 \\
\hline $\begin{array}{l}\text { Dark-anaerobic } \\
\text { ( } 96 \text { hour) }\end{array}$ & 260 & 0.078 & 25.7 & 0.013 \\
\hline $\begin{array}{l}\text { Dark-micro oxygen } \\
\text { ( } 96 \text { hour) }\end{array}$ & 258 & 0.077 & 25.5 & 0.012 \\
\hline $\begin{array}{l}\text { Light-aerobic } \\
\text { (96 hour) }\end{array}$ & 270 & 0.081 & 26.7 & 0.015 \\
\hline $\begin{array}{l}\text { Light-anaerobic } \\
\text { ( } 96 \text { hour) }\end{array}$ & 3000 & 0.915 & 297.0 & 0.096 \\
\hline $\begin{array}{l}\text { Light-micro oxygen } \\
\text { ( } 96 \text { hour) }\end{array}$ & 2400 & 0.720 & 237.6 & 0.075 \\
\hline
\end{tabular}

Table. 3 The relative expression level of $h k$ gene under different light and oxygen conditions at 0, 96 hours in: (A) soybean protein wastewater (B) starch wastewater 


\section{$h k(\mathrm{SPW}) \quad h k(\mathrm{sW})$}

All light-oxygen $\quad 0 \quad 0$

(0 hour)

Dark-aerobic $\quad 0 \quad 0$

(96 hour)

Dark-anaerobic $\quad 0 \quad 0$

(96 hour)

Dark-micro oxygen 00

(96 hour)

Light-aerobic

0

0

(96 hour)

Light-anaerobic

5.4

5.7

(96 hour)

Light-micro oxygen

(96 hour)

\section{Figures}

(A)

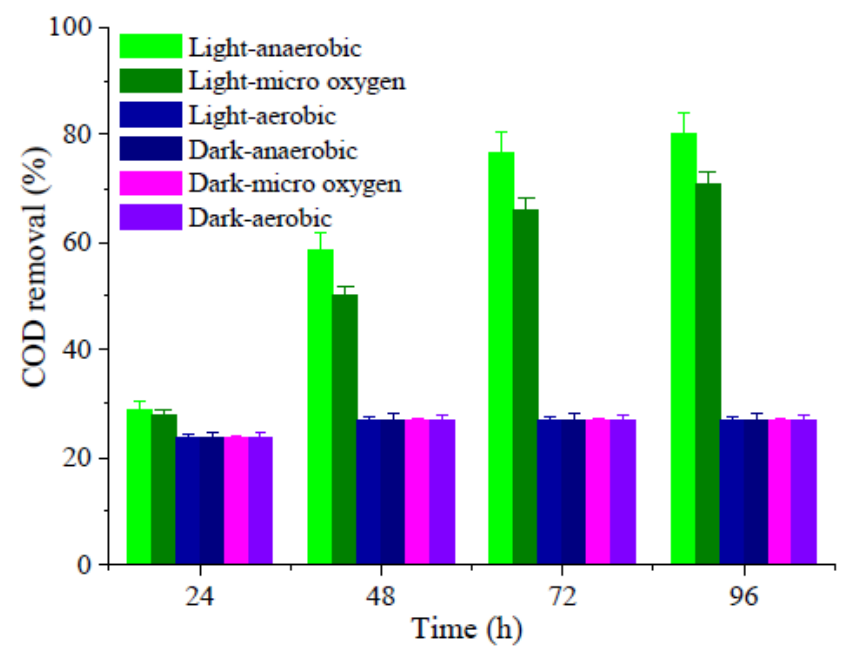

(B)

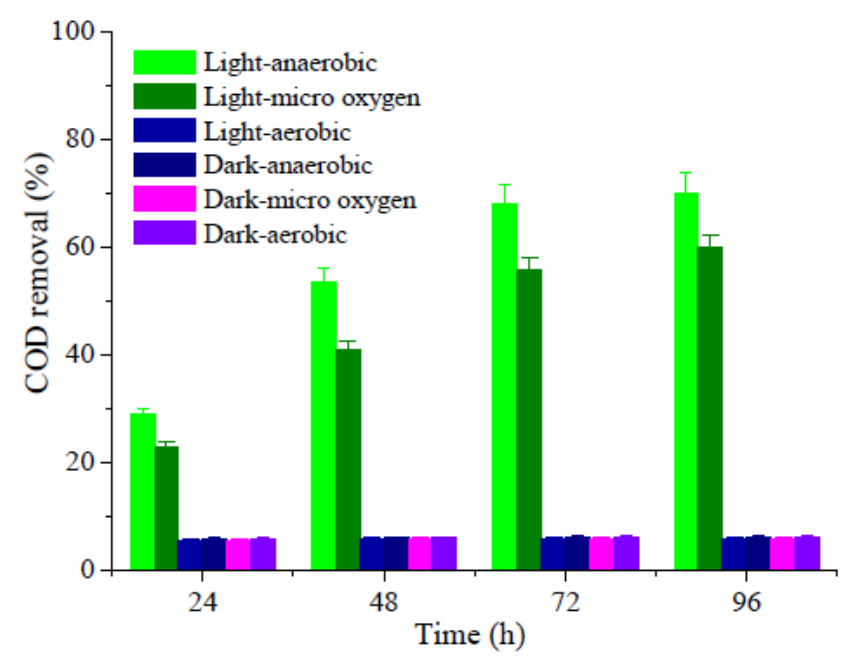

Figure 1 
The effect of light-oxygen conditions on R. gelatinosus direct treatment of wastewaters containing macromolecules organic (A) COD removal for soybean protein wastewater (B) COD removal for starch wastewater

(A)

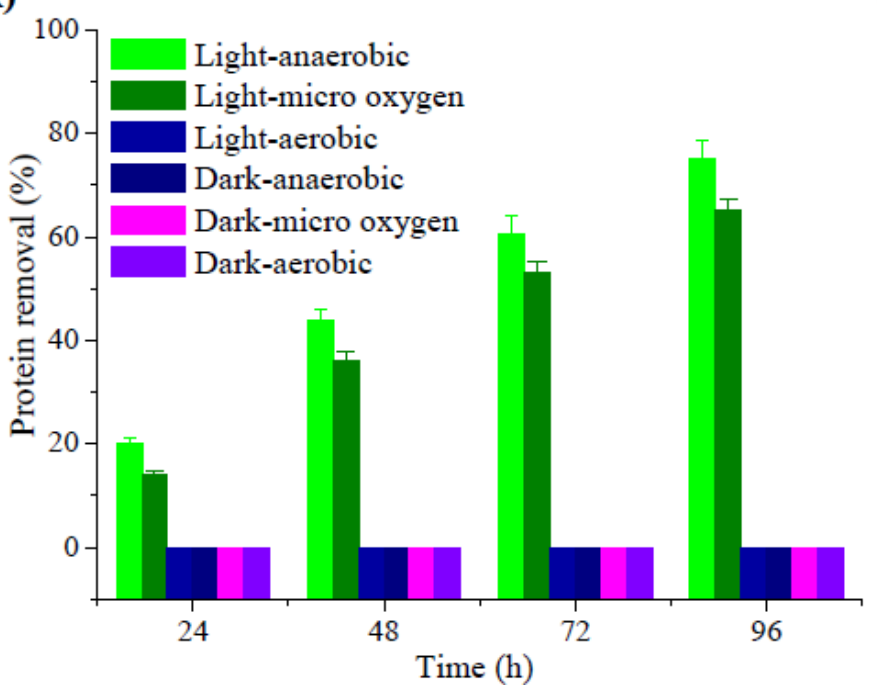

(B)

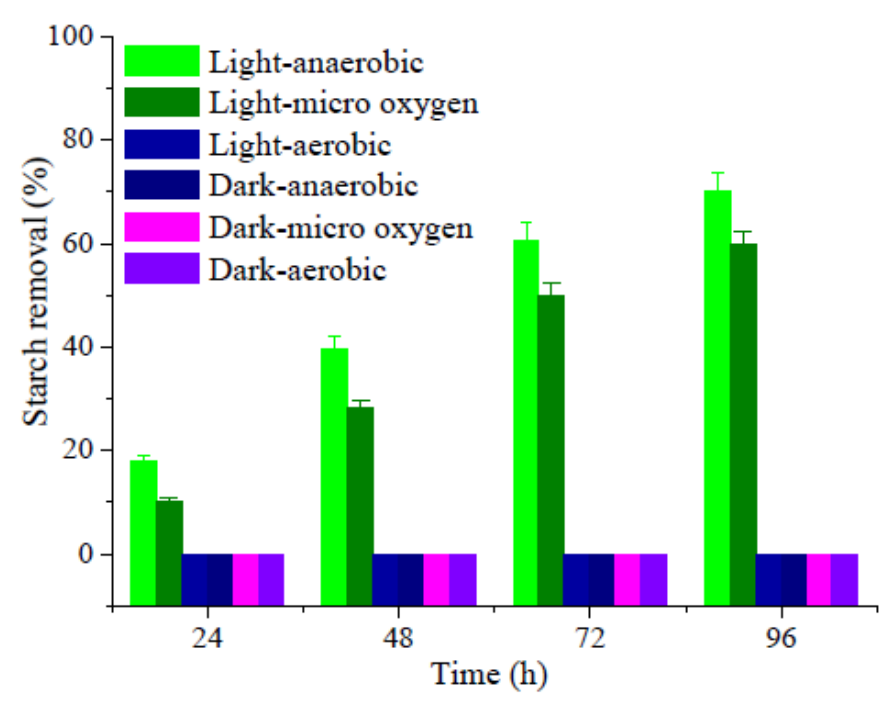

Figure 2

The impact of light-oxygen conditions on the protein removal in soybean protein wastewater and starch removal in starch wastewater (A) protein removal in soybean protein wastewater (B) starch removal in starch wastewater

(A)

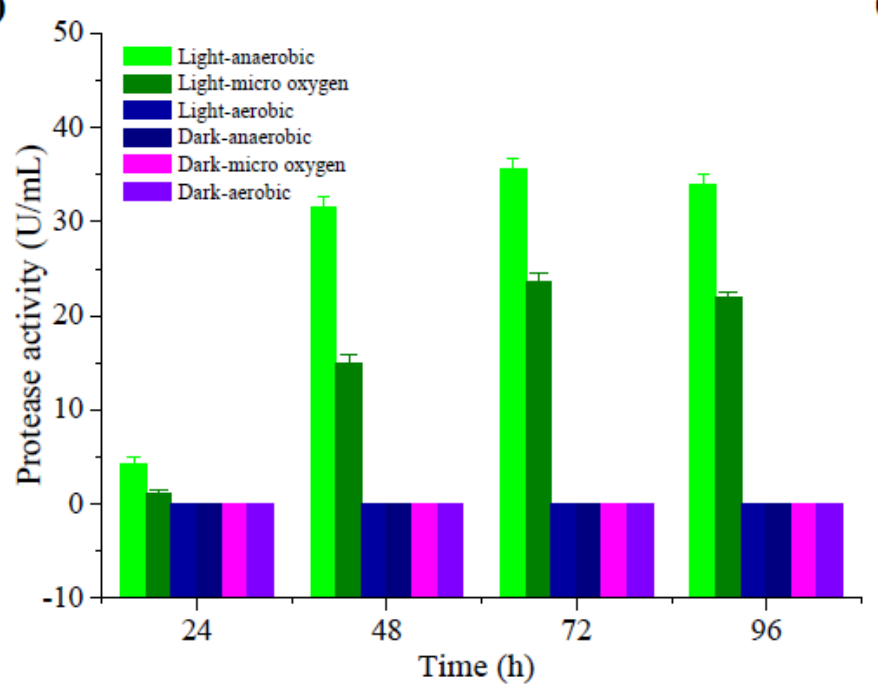

(B)

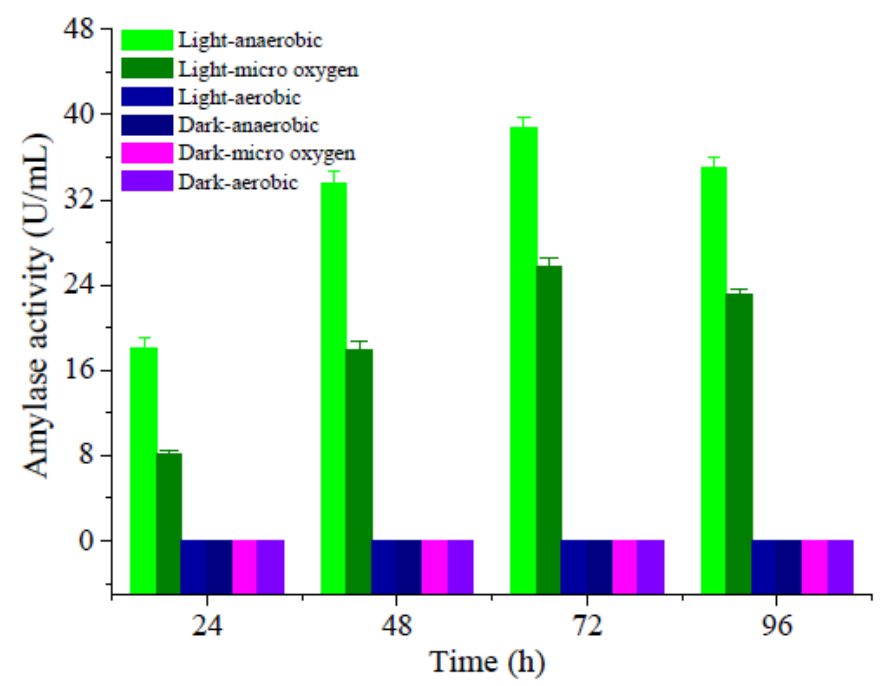

\section{Figure 3}

The effect of light-oxygen conditions on the protease activity in soybean protein wastewater and amylase activity in starch wastewater (A) protease activity in soybean protein wastewater (B) amylase activity in starch wastewater

\section{Supplementary Files}


This is a list of supplementary files associated with this preprint. Click to download.

- SupportingInformation.pdf 